UDC 316.44

BBK 60.54

\title{
HOUSING IDENTIFICATION OF CITIZENS AS A REFLECTION OF HOUSING INEQUALITY (BASED ON THREE CITIES OF KIROV REGION) ${ }^{1}$
}

\author{
Maria M. Starikova \\ Vyatka State University, Kirov, Russian Federation
}

\begin{abstract}
The subject of discussion in the article is housing inequality in a region on the example of cities in Kirov region. The author analyzes the content components of housing inequality, environmental and personal resources that promote and impede the preservation and improvement of housing status. The empirical base of the study was the results of a semi-formalized survey of citizens and expert interviews with realtors conducted in summer 2018 in three cities of Kirov region: Kirov, Vyatskiye Polyany and Kirovo-Chepetsk. The housing "portraits" of citizens are presented, the specificity of the housing plans, practices and self-identification of residents of regional and district cities is analyzed. The empirical study leads to the conclusion that the housing mentality of citizens is characterized by "healthy optimism" and relatively low demands, since the majority of respondents, even against the background of modest opportunities and a "bunch" of housing problems, highly appreciate the quality of their housing and are generally satisfied with its condition. Housing mobility of citizens is mainly reduced to movements within the same housing class. Radical improvements at the expense of available resources can afford only a few, although the population is increasingly using borrowed funds for the arrangement.
\end{abstract}

Key words: housing identification, housing stock, housing infrastructure, stratification, city, social inequality, deprivation.

УДК 316.44

ББК 60.54

\section{ЖИЛИЩНАЯ ИДЕНТИФИКАЦИЯ ГОРОЖАН КАК ОТРАЖЕНИЕ ЖИЛИЩНОГО НЕРАВЕНСТВА (НА ПРИМЕРЕ ТРЕХ ГОРОДОВ КИРОВСКОЙ ОБЛАСТИ) ${ }^{1}$}

\author{
Мария Михайловна Старикова \\ Вятский государственный университет, г. Киров, Российская Федерация
}

\begin{abstract}
Аннотация. Предметом обсуждения в статье является жилищное неравенство в регионе на примере городов Кировской области. Основное внимание уделено решению взаимосвязанных задач: анализу социальных изменений, определяющих сущность жилищной стратификации и формирование новых запросов различных социальных субъектов к жилищным условиям и определению функций и значимости жилья для горожан, их жилищной самоидентификации как основы выделения жилищных классов населения. Автором проведен анализ содержательных компонентов жилищного неравенства, описаны средовые и личностные ресурсы, способствующие и препятствующие сохранению и повышению жилищного статуса. Эмпирической базой исследования послужили результаты полуформализованного опроса горожан и экспертные интервью с риелторами, проведенные летом 2018 г. в трех городах Кировской области: Кирове, Вятских Полянах и Кирово-Чепецке. Представлены жилищные «портреты» горожан, проанализирована специфика жилищных планов, практик и самоидентификации жителей регионального и районных городов. Наиболее проблемными характеристиками домов, по мнению горожан, во всех городах стали парковки, детские площадки, асфальтовое покрытие на придомовой территории, состояние подвалов, качество работы управляющих компаний и коммунальных служб. В силу депривации эти показатели
\end{abstract}




\section{СОЦИОЛОГИЯ И СОЦИАЛЬНЫЕ ТЕХНОЛОГИИ}

имеют больший вес в ранжировании в жилищной стратификации. Эмпирическое исследование позволило сделать вывод, что жилищный менталитет горожан отличается «здоровым оптимизмом» и относительно невысокими запросами, поскольку большинство респондентов даже на фоне скромных возможностей и «букета» жилищных проблем достаточно высоко оценивают качество своего жилья и в целом удовлетворены его состоянием. Жилищная мобильность горожан в основном сводится к перемещениям в пределах одного жилищного класса. Радикальные улучшения за счет имеющихся ресурсов могут позволить себе лишь единицы, хотя население все активнее использует заемные средства для обустройства.

Ключевые слова: жилищная идентификация, жилищный фонд, жилищная инфраструктура, стратификация, город, социальное неравенство, депривация.

\section{Введение}

Жилье является ярким маркером стратификации населения в городах, где часто бок о бок сосуществуют микрорайоны ветхих и элитных домов.

Во многих странах власти прикладывают определенные усилия для смягчения последствий жилищного неравенства. В европейских государствах существуют жилищные пособия в качестве мер поддержки наиболее ущемленных слоев населения [Griggs, Kemp 2012]. Для ряда стран сегодня характерен рост закрытых городов и общин, причем барьеры ставятся обычно для отгораживания от нежеланных слоев населения. Так, А. Borsdorf, R. Hildalgo и S.Vidal-Koppmann описывают типичные анклавы социального жилья в отдаленных районах Чили и Аргентины, где отсутствует даже общественный транспорт [Borsdorf, Hildalgo, Vidal-Koppmann 2016]. Авторы показывают, что при видимых сходствах процессов пространственной жилищной сегрегации в городах двух стран, эти процессы воспринимаются по-разному: этническая сегрегация перуанских иммигрантов рассматривается как проблема в Сантьяго (Чили), тогда как в Буэнос-Айресе интерпретируют развитие закрытых общин как процесс социальной модернизации.

\section{Обзор литературы}

M. Lux, P. Sunega и T. Katrňák анализируют влияние социальной стратификации на жилищное неравенство в постсоциалистической Чехии [Lux, Sunega, Katrňák 2013]. Авторы показывают, как жилищные отношения развивались в процессе экономических преобразований, выдвигая гипотезу, что с переходом к капиталистической модели и рынку жилищ- ное расслоение будет увеличиваться. Однако поляризации не происходит, и исследователи приходят к выводу о слабой взаимосвязи экономической и жилищной стратификации в Чехии.

Жилищная стратификация в формате поляризации характерна и для развивающихся стран, например, Шри-Ланки и ряда африканских государств [Niriella 2017; Page, Sunjo 2018]. Во многих странах «третьего мира» доминирует малоэтажное жилье, однако резкий рост цен на землю привел к тому, что частное жилье стало недоступным для низших слоев, и многие жители вынуждены переселяться за пределы городов и крупных поселений. Таким образом, растет уровень неравенства и связанная с ним социальная напряженность.

По мнению А.Н. Муфтаховой, в нашей стране жилищная стратификация имеет цикличный характер. «От господских и купеческих домов Российской Империи до пролетарского авангарда постреволюционного строительства, от точечных застроек времен С.М. Кирова до комфортабельных “сталинок” и трущоб “немецких” коттеджей, от хрущевских ликвидаций излишек в строительстве до уравниловки при массовой застройке "брежневок" - во все исторические периоды государство сохраняло неравенство условий обеспечения нуждающихся в жилье» [Муфтахова 2016, 88].

Становление рыночных отношений в России в начале 90 -х гг. ХХ в. потребовало поиска и разработки новых методологических подходов к решению и исследованию проблем жилищной сферы. В работах исследователей О.Э. Бессоновой [Бессонова 2011], А.Р. Галяутдинова и Р.М. Муллаянова [Галяутдинов, Муллаянов 2007], Н.Р. Корнева [Корнев 2005], А.А. Магай и Б.М. Мержанова [Магай, Мержанов 2002], 
Т.Ю. Овсянниковой [Овсянникова, Котова 2004], А.М. Акатновой, Н.Е. Тихоновой, Н.Н. Седовой [Тихонова, Акатнова, Седова 2007], А.И. Черных [Черных 1995], Р.М. Хазиева [Хазиев 2012] и других обосновываются экономические и правовые проблемы развития жилищно-коммунальной сферы и жилищной политики в рыночной экономике, анализируется воздействие жилищной реформы на образ и стиль жизни людей, социальную стратификацию.

Жилищная идентификация горожан является основой жилищной стратификации, которую Н.Р. Корнев определяет как «систему типов жилья, образующую иерархию на основе их характеристик и соотнесения с характеристиками находящихся в них домохозяйств» [Корнев 2005, 79].

В типологии новосибирских исследователей О.Э. Бессоновой и С.Г. Крапчан позиция семьи в жилищной стратификации определяется по признаку «просторности» проживания: количество жилой площади на одного человека, соотношение комнат и проживающих. Типология начинается с высшего класса (собственник благоустроенного отдельно стоящего дома с числом комнат больше, чем число жителей, и площадью более 18 кв. м на одного члена семьи) и заканчивается низшим классом (жители коммунальной квартиры) [Бессонова, Крапчан 1994].

В ряде работ представлены детальные описания и классификация жилищных классов населения на примере конкретных городов. Так, обращаясь к жилищному облику Сыктывкара, П.П. Кротов и соавторы попытались «показать в ландшафте зданий и квартир закономерности распределения в них людей в зависимости от принадлежности к экономическим и социально-демографическим группам». Исследователи из Коми приходят к выводу, что «субъективная оценка жилищных условий складывается от осознания жильцами статуса их жилищного класса в иерархии и от возможностей продвижения по ступеням иерархической лестницы жилищных классов» [Кротов, Буравой, Лыткина 2003, 84].

Основное внимание в данной работе уделено решению следующих задач:

1) обзор тенденций социальных изменений, определяющих сущность жилищной стратификации и формирование новых запросов различных социальных субъектов к жилищным условиям;

2) определение функций и значимости жилья для горожан, их жилищной самоидентификации как основы выделения жилищных классов населения.

В масштабном исследовании РАН 2005 г. «Собственность в жизни россиян: домыслы и реальность» подробно проанализировано, насколько удовлетворяли на тот момент наших сограждан их жилищные условия, каковы были перспективы их улучшения. По данным этого исследования, «за последние 3 года каждый десятый россиянин смог улучшить свои жилищные условия, причем только половина из них сделала это за счет строительства или покупки жилья на собственные средства. Основная масса желающих приобрести квартиру принадлежат к слоям населения с низкими и средними доходами. Это говорит о том, что спрос на квартиры в большинстве своем является неплатежеспособным» [Собственность в жизни россиян web]. Актуальность повторных сравнительных исследований через 15 лет не вызывает сомнений.

В последнее десятилетие происходят интенсивные социальные изменения, напрямую или косвенно отражающиеся на стратификации, жилищном статусе и жилищных запpocax населения. «Для жилищной обеспеченности населения в терминах квадратных метров жилья характерно высокое неравенство. Значительные различия цен жилья по регионам, а также в разрезе типов населенных пунктов усиливают дифференциацию населения по стоимости имеющегося в собственности жилья). Однако в результате недавних изменений в законодательстве Росстат уже третий год не может собрать полную информацию о состоянии жилищного фонда РФ. Жилищные условия отдельных групп домашних хозяйств обычно изучаются методом выборочных обследований населения, с определенной статистической погрешностью которых приходится мириться [Бурдяк 2015, 287].

Как отмечает О.И. Шкаратан, «официально в стране провозглашено социальное государство. На сегодняшний день в России сложилась парадоксальная ситуация. Формально в стране действительно существуют разнооб- 
разные системы социальных льгот и выплат, охватывающие в общей сложности больше половины населения... Однако при этом крайне медленно сокращается доля живущих в нищете россиян... жилищное строительство почти не сказывается на улучшении положения социальных низов» [Шкаратан 2018, 21].

«Процесс расслоения городского населения и социально-пространственной сегрегации прослеживается в России как тенденция, постоянно набирающая темп. Продолжение жилищной политики в том виде, в каком она проводится сегодня, скорее всего приведет к тому, что уже в ближайшем будущем дифференциация населения по размерам и качеству жилья (включая его местоположение) возрастет и станет значимым фактором социальных отношений» [Гришанов 2004, 90].

Таким образом, «относительная автономность трех классов советской модели жилищного, экономического и социального в послесоветский период значительно ослабевает, сближая эти классы и закладывая основы жилищной сегрегации, характерной для капиталистического города» [Кротов, Буравой, Лыткина 2003, 92].

Наиболее сложный вопрос исследования связан с жилищным менталитетом населения. Под жилищным менталитетом П.П. Кротов и соавторы понимают «самоидентификацию, осознание индивидом собственной принадлежности к определенному жилищному классу, его ценностные ориентации. Вопросы, которые возникают в этой связи, касаются различий между представителями жилищных классов, во-первых, в их оценке собственного жилья; во-вторых, акцентировании проблем, с ним связанных, или уровнем депривации; в третьих, ассоциированностью со своим жилищным классом, или «микрорайонным патриотизмом» [Кротов, Буравой, Лыткина 2003, 84].

В данном исследовании мы придерживаемся традиционной позиции, высказанной О.И. Шкаратаном, согласно которой «индивиды рассматриваются либо как элементы социальной системы (структуры), и их действия в решающей степени детерминированы местом в системе социоэкономических отношений, либо как элементы культурной системы, и их действия определяются нормами и правилами, сложившимися в данной культуре (на- пример, в “культуре бедности” или в “культуpe среднего класса")» [Шкаратан 2018, 14].

«Сложности в определении жилищного статуса, оснований для формирования жилищных групп влекут проблему шкал измерения. Существующие шкалы типов жилья и жилищных условий достаточно неконсистентны (выделяют типы жилья по разным признакам - годам постройки, народным названиям (“сталинки”, “хрущевки”), развитости инфраструктуры)» [Полухина 2017, 596].

Вслед за В.А. Чулановым и В.Н. Кипшидзе выражаем согласие, что «возможность того или иного капитала фигурировать в роли фактора неравенства определяется ситуацией дефицита. Если доступ к тому или иному ресурсу открыт примерно одинаково для всех членов общества, то обладание им не дает преимуществ и не может выступать основой стратификации» [Чуланов, Кипшидзе 2009, 91].

\section{Материалы и методы}

В предыдущих работах автором уже была обоснована операциональная модель исследования жилищной стратификации, объединяющая объективные и субъективные критерии и детерминанты жилищного неравенства, которое как многомерное понятие можно рассматривать и с объектной, и с субъектной позиции. Под объектным уровнем жилищной стратификации мы будем понимать систему характеристик жилья, позволяющих выстроить его иерархию по уровню качества. На субъектном уровне жилищную стратификацию можно рассматривать сквозь призму позиций горожан в жилищной стратификации: наличие и размер жилищной собственности, количество квадратных метров на каждого проживающего совместно, количество объектов недвижимости в собственности, инвестиции в жилье и практики распоряжения им (обновление и поддержание ремонта, его ценовая категория), степень «жилищной ответственности» (взаимодействие с соседями, участие в распоряжении общедомовой собственностью), готовность к жилищной мобильности и планы на дальнейшее развитие. Таким образом можно определить состав и представленность в городах основных жилищных классов и страт и их соотношение с классическими параметрами социальной стратификации [Старикова 2018]. 
Основной исследовательский вопрос данной работы - как социальное неравенство отражено в жилищной идентификации горожан Кировской области, типичного для России дотационного региона. Также мы хотели проверить, существуют ли различия в жилищном неравенстве между региональным и районными городами.

Для ответа на поставленные вопросы в Кировской области в 2018 г. автором было проведено комплексное социологическое исследование, включавшее ряд экспертных интервью с риелторами $(N=20)$ и полуформализованный квартирный опрос горожан по маршрутизированной выборке в каждом городе (с соблюдением квот по полу и возрасту в соответствии с данными областной статистики, $N=923$ ).

Исследование проводилось в региональном центре г. Кирове (население 507 тыс. чел.) и двух наиболее крупных областных городах: Кирово-Чепецке (население 72 тыс. чел.) и Вятских Полянах (население 32 тыс. чел.). В Кирове опрошено 541 человек, в Кирово-Чепецке - 188, в Вятских Полянах - 194 жителя. Во всех городах имеются градообразующие предприятия крупной промышленности, однако тип застройки городов и история развития несколько отличаются. Спецификой Вятских Полян является тип застройки города - почти половина всех домов - одно-двухэтажные частные дома. В Кирове и Кирово-Чепецке также имеются частные индивидуальные дома в городской черте, однако в соотношении с многоквартирными домами их доля не- значительна и, кроме того, одноэтажные частные дома практически не встречаются в центре и близких к центру микрорайонах, поэтому они практически не попали в выборку.

В ходе маршрутизированного массового опроса контролировалось попадание в выборку разных типов жилья (кирпичных, панельных, деревянных домов в соответствии с типом застройки в городе, домов различных периодов застройки).

В каждом многоквартирном доме опрашивались жители 5-6 квартир, в каждой квартире на вопросы отвечал только один респондент, преимущественно владелец или ответственный квартиросъемщик, в случае его отсутствия - любой взрослый член домохозяйства.

\section{Результаты исследования}

Принципиальным для жилищного положения сегодня является уровень доходов горожан, поскольку жилищные блага достаются в основном путем экономических вложений (табл. 1).

Уровень потребления коррелируют с возможностями жителей целенаправленно инвестировать средства в жилищное развитие (см. табл. 2).

Судя по ответам, треть респондентов в принципе не могут вкладывать средства в улучшение жилищных условий. Большинство респондентов могут позволить себе лишь незначительные обновления, инвестиции в жилье доступны примерно десятой части горожан.

Таблица 1

Оцените, пожалуйста, уровень Вашей материальной обеспеченности за последние полгода (\% от опрошенных, $N=923)$

\begin{tabular}{|l|c|c|c|}
\hline \multicolumn{1}{|c|}{ Варианты ответов } & Вятские Поляны & кирово-Чепецк & Киров \\
\hline $\begin{array}{l}\text { Денег часто не хватает даже на самое недорогое: еду, } \\
\text { одежду, гигиену... }\end{array}$ & 11,9 & 15,4 & 9,4 \\
\hline $\begin{array}{l}\text { Денег хватает только на необходимые продукты } \\
\text { питания и необходимую одежду }\end{array}$ & 22,6 & 23,9 & 25,1 \\
\hline $\begin{array}{l}\text { Денег вполне хватает на продукты питания и одежду, } \\
\text { однако крупные покупки (например, бытовая техника, } \\
\text { мебель) требуют накоплений или кредита }\end{array}$ & 53,6 & 42,6 & 52,5 \\
\hline $\begin{array}{l}\text { Денег хватает на крупные покупки, но приобретение } \\
\text { хорошей машины или квартиры требует накоплений } \\
\text { в течение 2-3 лет или долгосрочного кредита }\end{array}$ & 10,8 & 17,0 & 12,0 \\
\hline $\begin{array}{l}\text { Можем позволить себе купить хорошую машину или } \\
\text { квартиру }\end{array}$ & 1,0 & 1,1 & 0,9 \\
\hline Итого & $\mathbf{1 0 0 , 0}$ & $\mathbf{1 0 0 , 0}$ & $\mathbf{1 0 0 , 0}$ \\
\hline
\end{tabular}




\section{СОЦИОЛОГИЯ И СОЦИАЛЬНЫЕ ТЕХНОЛОГИИ}

Причем поляризация населения по доходам наиболее выражена в Кирово-Чепецке. При этом для каждого третьего горожанина характерна жизнь в кредит.

Наиболее заметны различия между городами в уровне образования жителей. Формально кировчане являются более «высокообразованными» (на наш взгляд, в силу большей доступности высших ступеней образования в самом городе).

Можно судить, что по базовым шкалам социальной стратификации (доходам и образованию) около трети жителей изучаемых городов относятся к низшему классу, а большинство - к «базовому» слою населения (в терминах Т.И. Заславской промежуточный между низшим и средним классами). Надо предполагать, что и жилищные условия, и статусы соответствуют базовым стратификационным характеристикам.

\section{Жилищная обеспеченность горожан}

Для определения жилищных статусов горожан мы выделили ряд шкал в анкете (размерностью 72 вопроса), которые позво- ляют проанализировать обладание горожан тем или иным видом собственности и ее характеристики, степень удовлетворенности качеством жилья.

Мы поинтересовались у респондентов размером их жилья в расчете на каждого проживающего (табл. 3). Примерно 45 \% жителей Кирова и Кирово-Чепецка испытывают дефицит жилой площади (по стандарту социальная норма жилья 18 кв. м на человека). Дефицит жилой площади уже дает основания думать, что жилищный статус жильцов относительно низкий. В Вятских Полянах лишь треть горожан живут в стесненных условиях, зато четверть имеют более 26 кв. м на каждого совместно проживающего. Но, возможно, это связано с характером застройки города, где почти половину домов составляют частные одноэтажные дома (самостоятельной постройки, позволяющей сделать жилье более просторным).

Примерно половина горожан живут нуклеарно (в одиночку или вдвоем). Меньше всего больших семей (по 4 и более жильцов в одной квартире) в Вятских Полянах - 16 \%. В Кирово-Чепецке и Кирове примерно каждый четвер-

Таблица 2

Какую максимальную сумму Вы могли бы откладывать, чтобы, например, выплачивать ипотеку за приобретенное жилье или целенаправленно копить на первоначальный взнос/ремонт и т. п.? (\% от опрошенных, $N=923$ )

\begin{tabular}{|l|c|c|c|}
\hline \multicolumn{1}{|c|}{ Варианты ответов } & Вятские Поляны & Кирово-Чепецк & Киров \\
\hline Нисколько & 29,4 & 38,8 & 34,6 \\
\hline До 5 тыс. руб. & 22,1 & 18,1 & 23,1 \\
\hline До 10 тыс. руб. & 21,1 & 14,9 & 14,8 \\
\hline До 20 тыс. руб. & 9,8 & 10,7 & 14,3 \\
\hline Больше 20 тыс. руб. & 2,1 & 0,5 & 3,3 \\
\hline Затрудняюсь ответить & 15,5 & 17 & 10 \\
\hline Итого & $\mathbf{1 0 0 , 0}$ & $\mathbf{1 0 0 , 0}$ & $\mathbf{1 0 0 , 0}$ \\
\hline
\end{tabular}

Таблица 3

Сколько (примерно) общей площади в квадратных метрах приходится на каждого члена Вашей семьи? (\% от опрошенных, $N=923)$

\begin{tabular}{|l|c|c|c|}
\hline \multicolumn{1}{|c|}{ Варианты ответов } & Вятские Поляны & Кирово-Чепецк & Киров \\
\hline $5-10$ кв. м & 12,8 & 21,3 & 17,7 \\
\hline $11-15$ кв. м & 20,1 & 24,5 & 26,8 \\
\hline $16-20$ кв. м & 24,7 & 18,6 & 20,3 \\
\hline $21-25$ кв. м & 10,3 & 14,4 & 12,6 \\
\hline 26 и более & 25,3 & 17,0 & 17,7 \\
\hline Затрудняюсь ответить & 6,7 & 4,3 & 4,8 \\
\hline Итого & $\mathbf{1 0 0 , 0}$ & $\mathbf{1 0 0 , 0}$ & $\mathbf{1 0 0 , 0}$ \\
\hline
\end{tabular}


тый горожанин проживает совместно более чем с тремя домочадцами. При этом лишь $20 \%$ респондентов из Кирова и 25 \% из Кирово-Чепецка ответили, что живут в 3-комнатной квартире либо большей по числу комнат. Треть кировчан проживает в однокомнатных квартирах. Соответственно можно констатировать большую скученность и дефицит личного жилищного пространства во многих семьях. Наиболее благоприятная ситуация сложилась в Вятских Полянах, где однокомнатные квартиры скорее исключение из правил - в них проживает лишь $13 \%$ населения (для сравнения в Кирово-Чепецке - $19 \%$, в Кирове - 35,5 \%).
Однако обеспеченность квадратными метрами и индивидуализированной территорией (своя комната на каждого проживающего) не всегда сочетается с другими немаловажными критериями качества жилья, влияющими на уровень комфорта проживания и положение в жилищной иерархии. Мы проанализировали средние оценки по уровню удовлетворенности и состоянию ряда важных показателей качества жилья (табл. 4). Для анализа использовали также показатель дисперсии оценок среднего, чтобы видеть те параметры, в которых оценки жителей значимо различаются и происходит поляризация.

Таблица 4

В каком состоянии находятся следующие показатели

Вашего многоквартирного дома и микрорайона? (оцените по шкале от 1 до 5, где 1 - «в ужасном», 5 - «в отличном», полужирным отмечены показатели, отличающиеся в лучиую сторону среди трех городов, курсивом - в худшую, полужирным курсивом - высокая дисперсия ответов)

\begin{tabular}{|c|c|c|c|c|c|c|}
\hline \multirow[t]{2}{*}{ Показатель } & \multicolumn{2}{|c|}{ Киров } & \multicolumn{2}{|c|}{ Кирово-Чепецк } & \multicolumn{2}{|c|}{ Вятские Поляны } \\
\hline & среднее & дисперсия & среднее & дисперсия & среднее & дисперсия \\
\hline 1.Автомобильные парковки & 3,1 & 1,9 & 2,6 & 1,6 & 2,8 & 1,9 \\
\hline 2. Детские площадки & 3,0 & 2,2 & 2,8 & 2,0 & 2,5 & 2,1 \\
\hline $\begin{array}{l}\text { 3. Асфальтовое покрытие } \\
\text { во дворе }\end{array}$ & 3,1 & 2,1 & 2,8 & 1,5 & 2,5 & 2,0 \\
\hline 4. Состояние крыши & 3,9 & 1,3 & 3,7 & 1,1 & 3,7 & 1,9 \\
\hline 5. Состояние подъезда & 3,6 & 1,4 & 3,6 & 1,0 & 3,5 & 1,2 \\
\hline 6. Состояние подвала & 3,1 & 1,8 & 2,9 & 1,3 & 2,9 & 2,0 \\
\hline $\begin{array}{l}\text { 7. Система } \\
\text { видеонаблюдения }\end{array}$ & 3,6 & 2,7 & 2,7 & 1,4 & 3,0 & 2,4 \\
\hline 8. Помещение для колясок & 2,8 & 2,4 & 2,1 & 1,5 & 2,3 & 2,3 \\
\hline 9. Состояние лифта & 3,8 & 1,3 & 3,0 & 1,8 & 3,4 & 1,8 \\
\hline 10. Стены дома & 3,5 & 1,4 & 3,5 & 0,9 & 3,6 & 1,3 \\
\hline $\begin{array}{l}\text { 11. Состояние водопровода } \\
\text { и канализации }\end{array}$ & 3,7 & 1,3 & 3,6 & 0,8 & 3,9 & 1,2 \\
\hline 12. Наличие пандусов & 3,7 & 2,1 & 2,6 & 2,2 & 2,3 & 2,7 \\
\hline $\begin{array}{l}\text { 13. Отопление в холодный } \\
\text { период }\end{array}$ & 4,3 & 1,0 & 4,2 & 0,8 & 4,4 & 0,9 \\
\hline $\begin{array}{l}\text { 14. Освещение вокруг дома } \\
\text { и в подъезде }\end{array}$ & 3,9 & 1,2 & 4,1 & 1,0 & 3,2 & 1,7 \\
\hline $\begin{array}{l}\text { 15. Чистота на придомовой } \\
\text { территории }\end{array}$ & 3,8 & 1,3 & 4,1 & 0,9 & 4,1 & 1,0 \\
\hline $\begin{array}{l}\text { 16. Состояние } \\
\text { мусоропровода, мусорных } \\
\text { баков }\end{array}$ & 3,8 & 1,3 & 3,7 & 1,2 & 3,7 & 1,9 \\
\hline $\begin{array}{l}\text { 17. Работа управляющей } \\
\text { компании }\end{array}$ & 3,5 & 1,4 & 3,3 & 1,1 & 2,9 & 1,5 \\
\hline $\begin{array}{l}\text { 18. Озеленение на } \\
\text { придомовой территории }\end{array}$ & 3,5 & 1,6 & 3,5 & 1,4 & 3,9 & 1,4 \\
\hline 19. Слышимость в квартире & 3,1 & 1,7 & 3,0 & 1,5 & 3,5 & 1,2 \\
\hline $\begin{array}{l}\text { 20. Состояние экологии в } \\
\text { микрорайоне }\end{array}$ & 3,6 & 1,3 & 3,3 & 1,1 & 3,9 & 1,2 \\
\hline
\end{tabular}


Из 20 параметров большинство значимо не отличаются по средним оценкам жителей трех городов. Меньше всего волнует горожан состояние крыши и подъезда в целом (оценки выше 3,5 по 5-балльной шкале). Наиболее проблемными характеристиками домов во всех городах стали парковки, детские площадки, асфальтовое покрытие на придомовой территории, состояние подвалов, наличие помещений для колясок. В силу депривации эти показатели имеют больший вес в ранжировании домов в жилищной стратификации.

В открытых вопросах анкеты респонденты называли основные проблемы жилья, отражающие тенденции социальных изменений и жилищной стратификации. Многие подчеркивали, что значительно выросли расходы в семейном бюджете на оплату услуг ЖКХ, (цифры в платежках за 2-3-комнатные квартиры превышали 10 тысяч рублей в месяц). Таким образом, содержание даже относительно небольшого жилья начинает конкурировать с расходами на питание у большой части населения. При этом массово растет недовольство качеством оказываемых услуг и работой коммунальных служб и управляющих компаний по содержанию общедомового имущества: повсеместно разрастаются стихийные свалки из не вывезенного мусора вокруг жилых домов, зимой пробираться к дому приходится через баррикады неубранного снега; летне-осенний период примерно у трети жителей г. Кирова начинает ассоциироваться с отсутствием горячей (а порой и холодной) воды в кранах в течение 2-3 месяцев (при нормах отключения не более нескольких дней), поскольку водопроводная система города изношена до состояния ветхости. Программа капитального ремонта, несмотря на ежемесячные сборы с населения, не приводит к должному уровню восстановления и поддержания нормального состояния домов советской застройки, в результате все ярче проявляется поляризация жилищного фонда по качеству жилищных условий. Резко выросло число обращений и жалоб в прокуратуру и государственную жилищную инспекцию на бездействие и невыполнение своей работы коммунальными службами и управляющими компаниями. Сегодня жители многоквартирных домов, особенно советской застройки, часто ис- пытывают ощущение несправедливости и опасности за свою недвижимость, налицо высокие риски коммунального коллапса, безответственность и безнаказанность сотрудников управляющих компаний за халатную работу. Все это приводит к изменениям запросов горожан к качеству жилищных условий - снижению стоимости жилья советской застройки, повышению значимости факторов надежности, безопасности и новизны дома.

По некоторым показателям жилья изучаемые города значимо различаются: чуть больше высоких оценок поставили жители Кирова в показателях комфорта современных домов: наличии пандусов, системы видеонаблюдения, помещений для колясок, парковок, состоянии лифта. В целом почти все показатели качества жилья в Кирове несколько выше. Причина более благополучной ситуации в значительно большем количестве новых домов в региональном центре и лучшем по сравнению с районными городами финансировании содержания жилого фонда (что вовсе не означает его достаточности и полного объема для удовлетворения всех общедомовых жилищных нужд). Вятские Поляны выгодно отличаются от двух других городов состоянием экологии и озеленением на придомовой территории, однако как и Кирово-Чепецк имеют большой перечень низких оценок. Обращает на себя внимание факт большой дисперсии оценок по ряду показателей. Именно по ним жилищный фонд городов наиболее поляризован.

Немаловажную роль в жилищном неравенстве играет общее состояние дома, его «здоровье», выражающееся в степени износа. Как было отмечено выше риелторами на примере «хрущевок», не всегда фактический возраст дома совпадает с его изношенностью. Жилой фонд г. Кирова в данном вопросе за счет интенсивного жилищного строительства опять значимо выигрывает по сравнению с районными городами (32,5 \% жителей считают свой дом новым против 11,7 \% в КировоЧепецке и $15 \%$ в Вятских Полянах). Пятая часть домов в Кирове и каждый четвертый дом в Вятских Полянах, по мнению жильцов, имеют износ более 70 \% и нуждаются, как минимум, в срочном капитальном ремонте либо реконструкции, и уже только по этому показателю такие дома занимают низшее по- 
ложение в жилищной стратификации. В Кирово-Чепецке, по оценкам жителей, домов с износом более $70 \%$ несколько меньше - 13,3\%, сказывается более «молодой» возраст города в целом.

Однако на фоне низкого качества ряда коммунальных услуг и высокой степени износа домов, горожане склонны ставить своим домам достаточно высокие оценки (рис. 1).

Если на общее состояние дома жильцы часто повлиять не в силах, либо считают нерациональным вносить больший вклад в общедомовое имущество на фоне коллективного бездействия, то состояние ремонта внутри квартиры наиболее точно отражает возможности и желание вкладываться в свои жилищные условия и позволяет уточнить значимость жилья в системе жизненных ценностей горожан. С этой целью мы поинтересовались у респондентов, как давно они делали полноценный ремонт и как оценивают состояние своего жилья изнутри (табл. 5). Свежесть и качество ремонта резко влияют на стоимость и позицию в жилищной иерархии на уровне конкретного дома или квартиры. Мы сравнили, как часто горожане обновляют свое жилье. Только треть жителей Кирово-Чепецка и Вятских Полян делали ремонт в после-

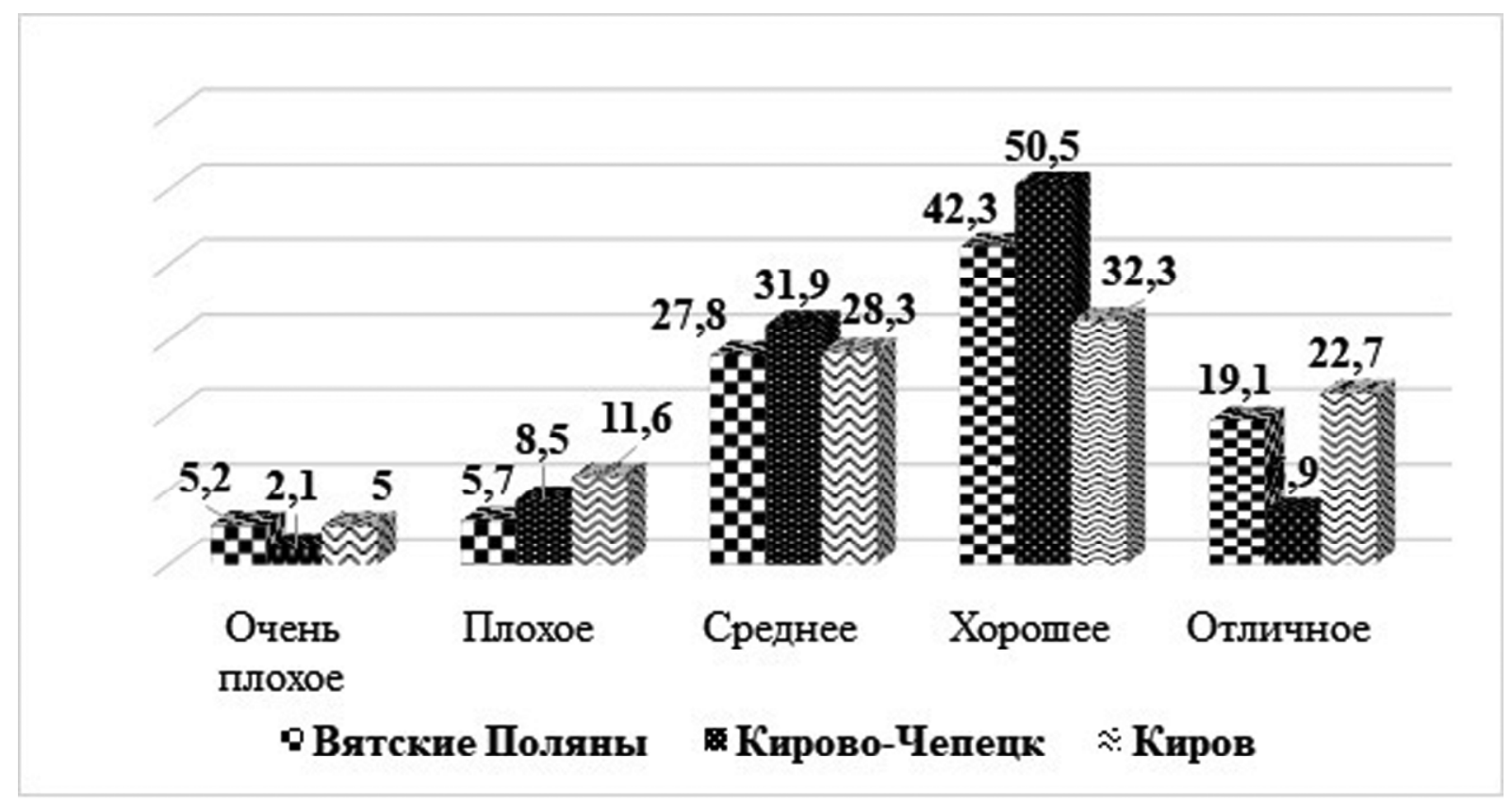

Рис. 1. Оцените состояние Вашего жилья «снаружи» (состояние дома в целом и придомовой территории) (\%îòîï đôøă í ûõ, $N=923, P=0,00$ )

Таблииа 5

Ваша квартира в данный момент отремонтирована (имеет хороший ремонт) на ... процентов? (\% от опрошенных, $N=923)$

\begin{tabular}{|l|c|c|c|}
\hline \multicolumn{1}{|c|}{ Варианты ответов } & Вятские Поляны & Кирово-Чепецк & Киров \\
\hline $0-10 \%$ & 3,6 & 7,4 & 4,1 \\
\hline $15-25 \%$ & 4,6 & 8,5 & 5,2 \\
\hline $30-50 \%$ & 30,4 & 28,7 & 25,7 \\
\hline $60-70 \%$ & 22,7 & 27,1 & 23,8 \\
\hline $80-90 \%$ & 30,9 & 18,1 & 23,1 \\
\hline На $100 \%$ & 6,2 & 9,0 & 17,4 \\
\hline Затрудняюсь ответить & 1,5 & 1,1 & 0,7 \\
\hline Итого & $\mathbf{1 0 0 , 0}$ & $\mathbf{1 0 0 , 0}$ & $\mathbf{1 0 0 , 0}$ \\
\hline
\end{tabular}


дние 3 года. Среди кировчан таких $44 \%$, что говорит о больших возможностях, жилищной мобильности и большей актуальности жилищного комфорта и престижа для жителей регионального центра.

Как видим, большинство жителей считают свое жилье отремонтированным более чем на $60 \%$, примерно треть жителей Кирова и Вятских Полян оценивают ремонт как полный и качественный (в Кирово-Чепецке 27 \%). В Кирове чуть меньше респондентов оценили состояние своих квартир на низкие баллы и больше высших баллов оценок ремонта, что дополнительно повышает среднюю стоимость жилья в региональном центре.

Чтобы оценки не были чисто субъективными, мы попросили респондентов указать конкретные достоинства своего жилья, которые они подчеркнули бы в случае продажи. Наиболее распространенными вариантами достоинств недвижимости оказались среди жителей Кирова большая общая площадь жилья (указали 33,5 \% респондентов), отдельно 27 \% подчеркнули большую площадь кухни как важного параметра комфорта и функциональности квартиры, 28 \% отметили отличный ремонт (что несколько меньше, чем в ответах на предыдущий вопрос - значит высокий процент отремонтированности не всегда соответствует отличному качеству), причем $22 \%$ отдельно подчеркнули отличный ремонт санузла (который часто является «визитной карточкой» квартиры). 35 \% указали, что их жилье имеет удобную и функциональную планировку (для сравнения, этот показатель отметили лишь 15-21\% жителей районных городов). Среди важных достоинств часто называли удобное расположение квартиры в доме и отличный вид из окна (что очень субъективно, поскольку некоторые предпочитают окна «во двор», где редко встретишь панорамные красивые городские пейзажи за исключением жителей последних этажей высотных домов). Каждый пятый отметил наличие большого балкона или лоджии, $15 \%$ имеют теплый пол, каждый десятый новые радиаторы отопления, низкую слышимость и спокойный район. Помимо предложенных вариантов от 2 до $5 \%$ респондентов самостоятельно указали такие достоинства, как наличие кондиционера, хорошую инфраструктуру и близость к центру города, солнечную сторону по расположению окон, редкое отключение горячей воды (что очень актуально для Кирова, где система городского водопровода изношена более чем на 80 \%). Жители районных городов называли практически те же самые достоинства, однако процент указавших был значительно ниже (примерно в 1,5-2 раза по каждому показателю). Наравне с кировчанами жители Кирово-Чепецка указывали большую площадь кухни, хороший вид из окна, даже чаще (28 \%) большой балкон.

По совокупности рассмотренных характеристик жилья можно судить, что основная доля домов в городах Кировской области соответствует «глубокому» экономклассу. Хотя непосредственно внутри своих квартир жители стараются содержать жилье в комфортном для себя состоянии ремонта. В целом распределение жилья с позиции жилищной стратификации соответствует невысоким социально-экономическим статусам большей части населения.

\section{Жилищный «менталитет» горожан}

Важный показатель жилищного менталитета в нашем исследовании - это степень идентификации респондентов с тем районом города, в котором они живут. В ходе исследования задавался вопрос о том, насколько жители привязаны к своему микрорайону и дому и готовы его поменять при переезде (см. табл. 6 и 7).

Степень привязанности к своему микрорайону значительно колеблется в зависимости от принадлежности дома, где проходил опрос, к определенному жилищному классу. Класс жилья и расположение дома относительно престижного городского центра или районов новостроек являются двумя основными взаимодополняющими факторами, определяющими «микрорайонный патриотизм», или психологическую привязанность жителей к району их проживания.

Готовность к жилищной мобильности сильно коррелирует с возрастом горожан: представители старшего поколения часто «психологически срастаются» с домом и районом, где прожили долгие годы и проявляют высокую жилищную «оседлость». «Женщина в возрасте, мужчина в возрасте, они привыкли к своему старому жилью, к рай- 
ону, они любят свой вонючий старенький дом и, если их заставляют переезжать, искать что-то новое, они все ходят и им ничего не нравится» (риелтор Наталья, агентство недвижимости «Этажи»).

Жилищная самоидентификация часто зависит и от способа, которым жилье человеку досталось (табл. 8 и 9). Сегодня рыночная экономика формирует у собственников привычку нести самостоятельную ответственность за все показатели жилищного обустройства. Ждать помощи и перекладывать ответственность становится бесперспективно.

Индикатором реализации мер по улучшению жилищных условий нуждающихся является статистика по обеспечению горожан жильем [Кировская область web] (табл. 8).
Как видно, «жилищная нужда» и спрос значительно превышает предложения государства и меры поддержки. Большинству горожан рассчитывать приходится только на свои силы. Несколько лучше ситуация обстоит в Кирово-Чепецке, однако стоит учитывать, что город более молодой и чуть лучше обстоят дела с ветхим и аварийным жилищным фондом.

Наиболее распространенным способом жилищного обустройства становится самостоятельная покупка недвижимости, причем процент ее совершивших повышается пропорционально размерам города. Риелторы единодушно отметили, что сегодня примерно 70-80 \% сделок по покупке жилья производится с привлечением ипотечных средств.

Насколько Вы привязаны к своему дому? (\% от опрошенных, $N=923$ )

\begin{tabular}{|l|c|c|c|}
\hline \multicolumn{1}{|c|}{ Варианты ответов } & Вятские Поляны & Кирово-Чепецк & Киров \\
\hline Я бы ни за что не сменил свое место жительства & 37,6 & 35,1 & 31,6 \\
\hline $\begin{array}{l}\text { Я не хочу переезжать, но если жизненные } \\
\text { обстоятельства потребуют, перееду }\end{array}$ & 35,6 & 35,1 & 32,5 \\
\hline $\begin{array}{l}\text { Я не привязан к своему дому, могу с легкостью } \\
\text { переехать }\end{array}$ & 24,2 & 23,9 & 32,0 \\
\hline Затрудняюсь ответить & 2,1 & 5,3 & 3,9 \\
\hline Итого & $\mathbf{9 9 , 5}$ & $\mathbf{9 9 , 5}$ & $\mathbf{1 0 0 , 0}$ \\
\hline Пропущенные & 0,5 & 0,5 & 0,0 \\
\hline Итого & $\mathbf{1 0 0 , 0}$ & $\mathbf{1 0 0 , 0}$ & $\mathbf{1 0 0 , 0}$ \\
\hline
\end{tabular}

Таблииа 7

Насколько Вы привязаны к своему микрорайону? (\% от опрошенных, $N=923)$

\begin{tabular}{|l|c|c|c|}
\hline \multicolumn{1}{|c|}{ Варианты ответов } & Вятские Поляны & Кирово-Чепецк & Киров \\
\hline Я бы ни за что не сменил свой микрорайон & 42,8 & 42,6 & 46,2 \\
\hline $\begin{array}{l}\text { Я не хочу переезжать, но если жизненные } \\
\text { обстоятельства этого потребуют, то сменю }\end{array}$ & 28,4 & 30,3 & 29,0 \\
\hline $\begin{array}{l}\text { Я не привязан к своему микрорайону, могу } \\
\text { с легкостью переехать в пределах города }\end{array}$ & 12,4 & 11,2 & 11,8 \\
\hline $\begin{array}{l}\text { Я не привязан к своему микрорайону, могу с } \\
\text { легкостью переехать даже в другой город }\end{array}$ & 13,9 & 12,2 & 10,9 \\
\hline Затрудняюсь ответить & 1,5 & 3,2 & 2,0 \\
\hline Не ответили & 1,0 & 0,5 & 0,0 \\
\hline Итого & $\mathbf{1 0 0 , 0}$ & $\mathbf{1 0 0 , 0}$ & $\mathbf{1 0 0 , 0}$ \\
\hline
\end{tabular}

Таблийа 8

Данные статистики по обеспечению граждан жильем за 2017 год

\begin{tabular}{|l|c|c|c|}
\hline \multicolumn{1}{|c|}{ Показатели } & Киров & Кирово-Чепецк & Вятские Поляны \\
\hline $\begin{array}{l}\text { Число семей, получивших жилые помещения и } \\
\text { улучшивших жилищные условия в отчетном году }\end{array}$ & 351 & 114 & 39 \\
\hline $\begin{array}{l}\text { Число семей, состоящих на учете в качестве нуж- } \\
\text { дающихся в жилых помещениях на конец года }\end{array}$ & 10858 & 1073 & 1266 \\
\hline
\end{tabular}




\section{СОЦИОЛОГИЯ И СОЦИАЛЬНЫЕ ТЕХНОЛОГИИ}

"До 14-го года без ипотеки покупала большая часть населения в коние года, к нам приходили люди и вкладьвали свои накопления, когда был рост экономики, когда люди даже если не богатые складывались вдвоем, втроем и покупали там студию, квартиру и т. д. - это накопление.

Наличка сейчас есть, но она связана большей частью не с накоплением, когда люди накапливали и вкладывали в жилье, с жизнью связано, переезды, наследство, вот они на севере продали, приехали - здесь купили, то есть это не накопления большей частью, это жизнь диктует» (риелтор Екатерина, агентство «Руснедвижимость»).

Каждый десятый житель Кирова смог получить жилье от государства, зато в районных городах значительная часть смогли получить жилье от работы (обычно за счет мо- нопредприятия в городе). Жители регионального центра чаще снимают жилье в аренду, однако это говорит скорее не о способе жилищного обустройства, а о миграции в центр жителей из районов и других городов.

Чтобы понимать потенциал и возможности повышения жилищного статуса, мы поинтересовались планами горожан на жилищное развитие в ближайшем будущем (табл. 10).

Риелторы достаточно подробно и структурированно описали основные запросы к жилью различных групп горожан: «Экономкласс любит, когда чтобы было все включено, чтобы была уже, допустим, кухня, ремонт чтобы был, мебель, и вот чем больше, тем лучше. Бедные в основном смотрят на иену - и чаще выбирают хуже квартиру, но по низкой иене, 100 тясяч рублей - это весомая разница для них. Благополучные

Каким образом Вам досталось жилье, в котором Вы сейчас живете?

Таблица 9 (\% от опрошенных, $N=923$ )

\begin{tabular}{|l|c|c|c|}
\hline \multicolumn{1}{|c|}{ Варианты ответов } & Вятские Поляны & Кирово-Чепецк & Киров \\
\hline От супруга/супруги & 6,2 & 1,6 & 2,8 \\
\hline От государства & 2,6 & 7,4 & 9,8 \\
\hline От работы & 10,8 & 14,4 & 5,2 \\
\hline От родителей по наследству & 21,6 & 16,5 & 9,1 \\
\hline От родственников по наследству & 3,6 & 3,2 & 1,8 \\
\hline Помогли дети & 1,0 & 1,6 & 1,3 \\
\hline Купили сами (накопили, взяли ипотеку) & 39,7 & 43,1 & 52,5 \\
\hline Я только член семьи собственника & 5,1 & 8,5 & 4,6 \\
\hline Снимаю в аренду, живу у родственников & 4,6 & 0,0 & 7,6 \\
\hline Другое (напишите) & 4,6 & 3,7 & 5,4 \\
\hline Итого & $\mathbf{1 0 0 , 0}$ & $\mathbf{1 0 0 , 0}$ & $\mathbf{1 0 0 , 0}$ \\
\hline
\end{tabular}

Таблиия 10

Какие способы улучшения жилищных условий для Вас наиболее вероятны в будущем? (\% от опрошенных, $N=923)$

\begin{tabular}{|l|r|r|r|}
\hline \multicolumn{1}{|c|}{ Варианты ответов } & Вятские Поляны & Кирово-Чепецк & Киров \\
\hline Получить наследство & 12,7 & 4,6 & 6,1 \\
\hline $\begin{array}{l}\text { Улучшить имеющееся жилье перепланировкой } \\
\text { или ремонтом }\end{array}$ & 24,3 & 29,7 & 26,6 \\
\hline Удачно выйти замуж & 3,3 & 5,1 & 2,6 \\
\hline Ипотека & 10,5 & 6,9 & 8,9 \\
\hline $\begin{array}{l}\text { Родить второго ребенка и использовать } \\
\text { материнский капитал }\end{array}$ & 6,1 & 5,7 & 8,2 \\
\hline Накопить и обменять свое жилье с доплатой & 21,0 & 24,0 & 24,0 \\
\hline Другое & 9,9 & 8,6 & 11,9 \\
\hline Затрудняюсь ответить & 24,9 & 25,1 & 27,1 \\
\hline Итого & $\mathbf{1 1 2 , 7}$ & $\mathbf{1 0 9 , 7}$ & $\mathbf{1 1 5 , 4}$ \\
\hline
\end{tabular}


M.M. Старикова. Жилищная идентификация горожан как отражение жилищного неравенства

же люди любят даже черновую отделку, например, без стяжки, наоборот, чтобы не было признаков жилья, жизни в этой квартире» (риелтор Светлана, агентство недвижимости «Этажи»).

\section{Заключение}

В целом стратегии жилищного обустройства горожан коррелируют с экономическим развитием регионов и состоянием жилищного фонда. Идентификация горожан на лестнице жилищной иерархии тесно связана с тенденциями социальных изменений - падением покупательной способности населения, повышением стоимости услуг ЖКХ и снижением их качества, диспропорциями показателей комфорта жилья, доступных жильцам аварийного, ветшающего жилья, домов советского периода и современной застройки. Большую часть населения центра региона можно отнести к базовому жилищному классу, чуть ниже среднего, но не опускающегося на жилищное и социальное «дно».

Наше исследование показало, что жилищная мобильность горожан в основном сводится к перемещениям в пределах одного жилищного класса. Радикальные улучшения за счет имеющихся ресурсов могут позволить себе лишь единицы, хотя население все активнее использует заемные средства для обустройства. Практически отсутствует нисходящая жилищная мобильность, хотя большие риски обесценивания жилья имеют жильцы домов с полувековым возрастом и старше. Состояние таких домов часто становится камнем преткновения между жильцами и обслуживающими организациями.

Для районных городов характерна меньшая поляризация и большая однородность жилищных страт, однако и меньшие возможности и интенсивность восходящего развития (в Кирово-Чепецке и Вятских Полянах за последние два десятилетия жилищное строительство резко сократилось). Стоит подчеркнуть, что жилищный менталитет горожан отличается «здоровым оптимизмом» и относительно невысокими запросами, поскольку большинство респондентов даже на фоне скромных возможностей и «букета» жилищных проблем достаточно высоко оценивают качество своего жилья и в целом удовлетворены его состоянием.

\section{ПРИМЕЧАНИЕ}

${ }^{1}$ Работа выполнена в рамках научного проекта № 18-011-00627 «Особенности жилищного неравенства в современных российских городах» при финансовой поддержке РФФИ.

The work was supported by the Russian Foundation for Basic Research (RFBR) in the framework of research project no. 18-011-00627 "Features of Hosing Inequality in Modern Russian Cities".

\section{СПИСОК ЛИТЕРАТУРЫ}

Бессонова 2011 - Бессонова О.Э. Жилищный раздаток и модернизация России. М.: Российская политическая энциклопедия (РОССПЭН), 2011.

Бессонова, Крапчан 1994 - Бессонова О.Э., Крапчан С.Г. Участие населения в приватизации жилья // Социологические исследования. 1994. № 8. С. 27-40.

Бурдяк 2015 - Бурдяк А.Я. Обеспеченность жильем в постсоветской России: неравенство и проблема поколений // Журнал исследований социальной политики. 2015. Т. 13, № 2. С. $273-288$.

Галяутдинов, Муллаянов 2007 - Галяутдинов А.P., Муллаянов Р.М. Метаморфозы реформы ЖКХ // Социологические исследования. 2007. № 11. C. 50-54.

Гришанов 2004 - Гришанов В. И. Неравенство в доходах и неравенство в качестве жилья // Жилищный вопрос как проблема социальной политики: сборник. М.: ИМЭПИ РАН, 2004. С. $78-92$.

Кировская область web - Кировская область. Федеральная служба государственной статистики // http://www.gks.ru/dbscripts/munst/ munst33/DBInet.cgi.

Корнев 2005 - Корнев Н.Р. Жилищная стратификация в центре Санкт-Петербурга // Социологические исследования. 2005. № 6. С. 77-85.

Кротов, Буравой, Лыткина 2003 - Кротов П.П., Буравой М., Лыткина Т.С. Жилищная стратификация города: рыночная эволюция советской модели. Сыктывкар: Коми научный центр УрО Российской АН, 2003.

Магай, Мержанов 2002 - Магай А.А., Мержанов Б.М. Какое жилище нам нужно в перспективе // Жилищное строительство. 2002. № 10. С. 4-6.

Мальцева, Шилкина, Махныткина 2016 - Мальиева А.В., Шилкина Н.Е., Махнылткина О.В. Обэмпирических индикаторах социальной 
структуры и социальной стратификации // Социологические исследования. 2016. № 12. C. $33-44$.

Муфтахова 2016- Муфтахова А.Н. Социальное неравенство в жилищной сфере и проблемы современной жилищной политики // Урбанистика. 2016. № 4. С. 86-93.

Овсянникова, Котова 2004 - Овсянникова Т.Ю., Котова O.В. Жилище в системе личных и общественных ценностей // Вестник ТГАСУ. 2004. № 1. C. 241-251.

Полухина 2017 - Полухина Е.В. Жилищная мобильность: направления социологического анализа // Журнал исследований социальной политики. 2017. Т. 15, № 4. С. 589-602.

Собственность в жизни россиян web - Собственность в жизни россиян. Аналитический доклад. М., 2005 // http:/www.isras.ru/files/File/ Socis/2005-11/property_paper.pdf.

Старикова 2018 - Старикова М.М. Жилищное неравенство в регионе (на примере трех городов Кировской области) // Социодинамика. 2018. № 12. C. 78-105.DOI: 10.25136/2409-7144.2018.12.28369.

Тихонова, Акатнова, Седова 2007 - Тихонова Н.Е., Акатнова А.М., Седова Н.Н. Жилищная обеспеченность и жилищная политика в современной России // Социологические исследования. 2007. № 1. С. 71-81.

Хазиев 2012 - Хазиев Р.М. Жизненное пространство населения в условиях реформирования жилищно-коммунальной сферы: автореф. дис. ... канд. социол. наук. Казань, 2012.

Черных 1995 - Черных А.И. Жилищный передел // Социологические исследования. 1995. № 10. С. 71-78.

Чуланов, Кипшидзе 2009 - Чуланов В.А., Кипшидзе B.Н. Концептуальные основания анализа социальной стратификации // Вестник ЮРГТУ (НПИ). 2009. № 3. С. 87-92.

Шкаратан 2018 - Шкаратан О.И. Социально-экономическое неравенство в современном мире и становление новых форм социального расслоения в России // Мир России. 2018. № 2. С. 6-35.

Borsdorf, Hildalgo, Vidal-Koppmann 2016 Borsdorf A., Hildalgo R., Vidal-Koppmann S. Social segregation and gated communities in Santiago de Chile and Buenos Aires. A comparison // Habitat International. 2016. No. 54. P. 18-27.

Griggs, Kemp 2012 - Griggs J., Kemp P.A. Housing Allowances as Income Support: Comparing European Welfare Regimes // International Journal of Housing Policy. 2012. No. 12. P. 391-412.

Lux, Sunega, Katrňák 2013 - Lux M., Sunega P., Katrñák T. Classes and castles: Impact of social stratification on housing inequality in post- socialist states // European Sociological Review. 2013. No. 2. P. 274-288.

Niriella 2017 - Niriella N.C. Emerging social-spatial polarisation within the housing market in Colombo, Sri Lanka // Journal of Urban Regeneration and Renewal. 2017. No. 11. P. 158-167.

Page, Sunjo 2018 - Page B., Sunjo E. Africa's middle class: building houses and constructing identities in the small town of Buea, Cameroon // Urban Geography. 2018. No. 1. P. 75-103.

\section{REFERENCES}

Bessonova O.E., 2011. Housing razdatok and modernization of Russia. Moscow, Russian Political Encyclopedia.

Bessonova O.E., Krapchan S.G., 1994. Participation of the population in housing privatization. Sotsiologicheskiye issledovaniya, no. 8, pp. 27-40.

Burdyak A.Y., 2015. Provision of housing in postSoviet Russia: inequality and the problem of generations. Zhurnal issledovaniy sotsial'noy politiki, vol. 13, no. 2, pp. 273-288.

Galyautdinov A.R., Mullayanov R.M., 2007. Metamorphosis of the housing and utilities reform. Sotsiologicheskiye issledovaniya, no. 11 , pp. 50-54.

Grishanov V.I., 2004. Income inequality and inequality in the quality of housing. Housing problem as a problem of social policy: a collection. Moscow, IIEPS RAS, pp. 78-92.

Kirov region. Federal State Statistics Service. URL: http://www.gks.ru/dbscripts/munst/munst33/ DBInet.cgi (accessed 10 February 2019).

Kornev N.R., 2005. Housing stratification in the center of St. Petersburg. Sotsiologicheskiye issledovaniya, no. 6, pp. 77-85.

Krotov P.P., Buravoi M, LytkinaT.S., 2003. Housing stratification of the city: the market evolution of the Soviet model. Syktyvkar, Komi Scientific Center, Ural Branch, Russian Academy of Sciences.

Magay A.A., Merzhanov B.M., 2002. What kind of housing do we need in the future. Zhilishchnoye stroitel'stvo, no. 10, pp. 4-6.

Maltseva A.V., Shilkina N.E., Makhnytkina O.V., 2016. On empirical indicators of social structure and social stratification. Sotsiologicheskiye issledovaniya, no. 12, pp. 33-44.

Muftakhova A.N., 2016. Social inequality in the housing sphere and the problems of modern housing policy. Urbanistika, no. 4, pp. 86-93.

Ovsyannikova, T.Y., Kotova, O.V., 2004. Dwelling in the system of personal and social values. Vestnik TGASU, no. 1, pp. 241-251. 
M.M. Старикова. Жилищная идентификация горожан как отражение жилищного неравенства

Polukhina E.V., 2017. Housing mobility: directions of sociological analysis. The Journal of Social Policy Studies, vol. 15, no. 4, pp. 589-602.

Property in the life of Russians. Analytical report. Moscow, 2005. URL: http://www.isras.ru/files/ File/Socis/2005-11/property_paper.pdf (accessed 10 February 2019).

Starikova M.M., 2018. Housing inequality in the region (on the example of three cities of the Kirov region. Sotsiodinamika, no. 12, pp. 78105. DOI: 10.25136/2409-7144.2018.12.28369.

Tikhonova N.E., Akatnova A.M., Sedova N.N., 2007. Housing security and housing policy in modern Russia. Sotsiologicheskiye issledovaniya, no. 1, pp. 71-81.

Khaziev R.M., 2012. Vital space of the population in the conditions of reforming the housing and communal sphere. autoabstract. dis. ... candidate of sociological sciences. Kazan.

Chernykh A.I., 1995. Housing redistribution. Sotsiologicheskiye issledovaniya, no. 10, pp. 71-78.

Chulanov V.A., Kipshidze V.N., 2009. Conceptual foundations of the analysis of social stratification. Vestnik YURGTU, no. 3, pp. 87-92.
Shkaratan O.I., 2018. Social and economic inequality in the modern world and the formation of new forms of social stratification in Russia. Mir Rossii, no. 2, pp. 6-35.

BorsdorfA., Hildalgo R., Vidal-Koppmann S., 2016. Social segregation and gated communities in Santiago de Chile and Buenos Aires. A comparison. Habitat International, no. 54, pp. 18-27.

Griggs J., Kemp P.A., 2012. Housing Allowances as Income Support: Comparing European Welfare Regimes. International Journal of Housing Policy, no. 12, pp. 391-412.

Lux M., Sunega P., Katrňák T., 2013. Classes and castles: Impact of social stratification on housing inequality in post-socialist states. European Sociological Review, no. 2, pp. 274-288.

Niriella N.C., 2017. Emerging social-spatial polarisation within the housing market in Colombo, Sri Lanka. Journal of Urban Regeneration and Renewal, no. 11, pp. 158-167.

Page B., Sunjo E., 2018. Africa's middle class: building houses and constructing identities in the small town of Buea, Cameroon. Urban Geography, no. 1, pp. $75-103$.

\section{Information about the Author}

Maria M. Starikova, Candidate of Sciences (Sociology), Associate Professor, Department of Cultural Studies, Sociology and Philosophy, Vyatka State University, Moskovskaya St., 36, 610000 Kirov, Russian Federation, maria_kuzmina82@mail.ru, https://orcid.org/0000-0002-5820-8731

\section{Информация об авторе}

Мария Михайловна Старикова, кандидат социологических наук, доцент кафедры культурологии, социологии и философии, Вятский государственный университет, ул. Московская, 36, 610000 г. Киров, Российская Федерация, maria_kuzmina82@mail.ru, https://orcid.org/0000-0002-5820-8731 